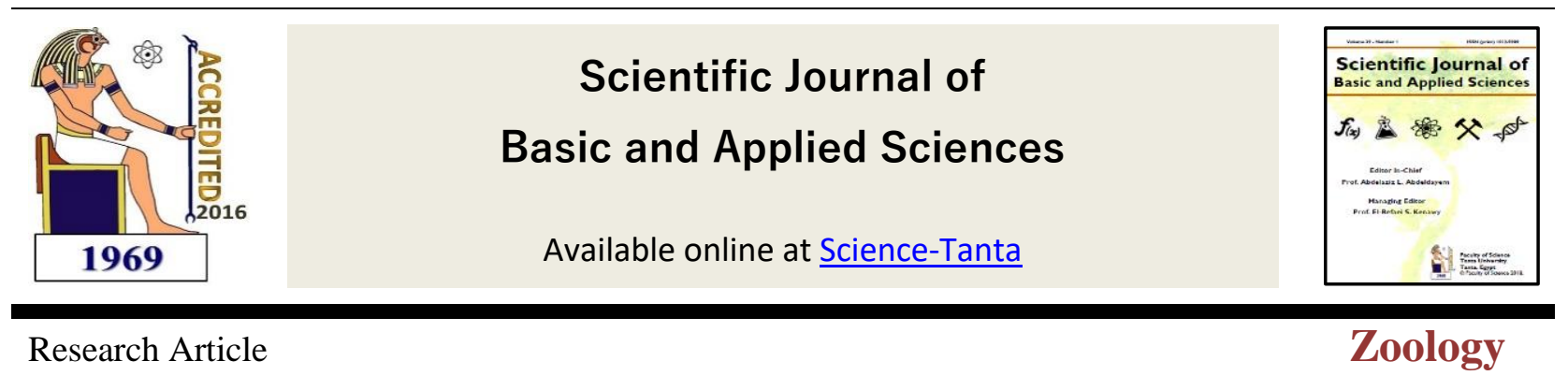

\title{
Evaluation of skeletal muscle changes during aging
}

\author{
Randa A. Alnajdi ${ }^{1}$, Abeer A. Alam-Eldeen ${ }^{1}$, Nabil K. El-Fiky ${ }^{1 *}$ and Abeer A. Khamis ${ }^{2}$ \\ 1. Zoology Department, Faculty of Science, Tanta University, Tanta 31527, Egypt \\ 2. Biochemistry Division, Chemistry Department, Faculty of Science, Tanta University, Tanta 31527, Egypt \\ * Correspondence: Nabil K. El-Fiky; Zoology Department, Faculty of Science, Tanta University, Tanta 31527, \\ Egypt; Email: elfiky.nabil@gmail.com
}

\section{KEY WORDS}

\section{Quercetin,}

Antioxidant enzymes, Lipid peroxidation, Rat

List of Abbreviations:
$1 \mathrm{M}=$ one month,
$10 \mathrm{M}=$ ten months,
$\mathrm{SOD}=$ superoxide dismutase,
$\mathrm{GPx}=$ glutathione
peroxidase,
$\mathrm{MDA}=$ malondialdehyde

\begin{abstract}
The present study investigated the effect of supplementation of quercetin on changes in body weight, lipid peroxidation and antioxidant enzymes activities gastrocnemius muscular tissues in different rat ages (1M \& 10M). Average body weight of experimental rats was as follows: $1 \mathrm{M}(28.37 \pm 2.52 \mathrm{~g}), \& 10 \mathrm{M}(211.45 \pm 12.14 \mathrm{~g})$. Male rats were divided into two groups: control rats $(\mathrm{C} 1 \mathrm{M}, \mathrm{C} 10 \mathrm{M})$, fed on laboratory regular diet, and quercetin treatments (Q1M=0.108 $\mathrm{mg}, \mathrm{Q} 10 \mathrm{M}=0.86 \mathrm{mg})$. It was observed that the daily weight gain in quercetin group was higher than that of control group. In addition to normal growth, food consumption, and muscle mass, rat treated with the quercetin enriched diet did not exhibit obvious signs of toxicity including failure to groom or lethargy. Importantly, supplementation with quercetin did not result in unexpected deaths. Quercetin treatment increases the content of GPx in (1M) by $22.45 \%$, but decreasing GPx by $25.32 \%$ for $10 \mathrm{M}$, when compared with values of the control group. Quercetin treatment increases the content of SOD at different ages by $16.2 \% \& 68.15 \%$, for $1 \mathrm{M} \& 10 \mathrm{M}$, respectively, when compared with values of the control group. It was found that tissue MDA was increased by $168.8 \%$ \& $110.0 \%$ at $1 \mathrm{M} \& 10 \mathrm{M}$, respectively, when compared with value of control $1 \mathrm{M}$. When comparing quercetin treatments at different ages, it is noted the MDA content of muscular tissues decrease by $35.9 \%$ at $10 \mathrm{M}$, when compared with values of quercetin treatment $1 \mathrm{M}$. Skeletal muscle of non-treated animal (10M) showing marked hyalinization and fragmentation of muscle fibers whereas Skeletal muscle of Quercetintreated animal (10M) showing focal hyalinization of muscle fibers while the remaining bundles were within normal. Conclusion: Quercetin could be used as anti-aging modulator against changes in gastrocnemius muscle resulted in aging.
\end{abstract}

\section{Introduction}

Quercetin (3,3',4',5,7-pentahydroxyflavone) is a natural polyphenolic flavonoid commonly found in a sugar bonding form such as quercetin-3-glucoside (Q3G) or quercetin-4glucoside $(\mathrm{Q} 4 \mathrm{G})$. Flavonoids are found in leaves, flowers, roots, seeds, nuts, and barks 
and fulfill many biological functions including UV protection, pigmentation and antimicrobial defense. Quercetin levels in plants positively correlated with exposure to UVB radiation and its accumulation has been considered a natural protection against UV induced damage.

Quercetin is present in a number of plantderived foods. Apples with their skin (4.42 $\mathrm{mg} / \mathrm{g}$ ), raw celery $(3.50 \mathrm{mg} / \mathrm{g})$, raw chives (4.77 mg/g), unsweetened cocoa $(20.13 \mathrm{mg} / \mathrm{g})$, cookedonion $(19.36 \mathrm{mg} / \mathrm{g})$, yellow chili peppers $(50.63 \mathrm{mg} / \mathrm{g})$, dill $(55.15 \mathrm{mg} / \mathrm{g})$, and especially canned capers $(180.77 \mathrm{mg} / \mathrm{g})$ are food items that contains a higher-thanaverage content of quercetin (Garg et al., 2001). Quercetin expresses several physiological functions including antioxidant, anti-hyperglycemic, anti-inflammatory, cytoprotective, hepatoprotective and inhibition of lipopolysaccharide-induced nitric oxide production. In the gut quercetin is formed through hydrolysis of rutin by intestinal microorganisms. Studies in syndrome and diabetes have suggested its potential in the treatment of metabolic syndrome and diabetes.

Flavonoid antioxidants may act by a variety of ways including trapping of oxygencentered radicals, inhibition of enzymes involved in their production, chelation of transition metal ions involved in radicalforming processes such as the Fenton reaction, and regeneration of membrane-bound antioxidants such as $\alpha$-tocopherol (Bors et al. 1990, Harborne, 1994).

The purpose of this study was to investigate the effect of short-term supplementation of quercetin (14 days) on body weight gain, and oxidative markers the gastrocnemius muscles of rats of different ages.

\section{Material and Methods}

\subsection{Experimental animals}

Albino male rats $(\mathrm{N}=28)$ were divided into 2 groups as follows: 14 mice one month old $(36.42 \pm 2.43 \mathrm{~g}) \& 14$ mice ten months-old $(229.28 \pm 24.90 \mathrm{~g})$, as shown in (Table 1). Each group divided into 2 subgroups each consist of 7 rats fed a laboratory regular diet (Protein 25\%, Fat 5.0\%, Carbohydrate 47.5\%, Crude fiber $5.3 \%$, Ash $7.0 \%$ ), and the other subgroup fed a Lab. regular diet + quercetin which was suspended in distilled water and given orally after two weeks allowed for acclimation to experimental conditions. Each subgroup of mice was singly housed in cages in controlled environmental conditions (22$25^{\circ} \mathrm{C}$ ), with a $12-12 \mathrm{~h}$ light-dark cycle. Rats were arranged as follows:

1. Control (C1), (C10).

2. Experimental quercetin group $(\mathrm{Q} 1=0.108$ $\mathrm{mg} / \mathrm{ml}, \quad \mathrm{Q} 10=0.86 \mathrm{mg} / \mathrm{ml}$ ). All these treatments equivalent to $4 \mathrm{mg}$ quercetin / $\mathrm{kg}$ body weight / day.

\subsection{Sampling}

Random tissue specimens were collected from gastrocnemius muscles of treated and control groups under strict hygienic conditions to minimize the contamination or autolysis of the samples, then quickly either frozen in liquid nitrogen before storing at $-80{ }^{\circ} \mathrm{C}$ to be used for RNA extraction or preserved in neutral buffered formalin solution $(10 \%)$ for immunohistochemistry.

\subsection{Biochemical analysis}

The biomarkers, MDA levels, SOD, and GPx activities, were evaluated. Superoxide dismutase (SOD) activity was determined by measuring the decrease in hydrogen peroxide $\left(\mathrm{H}_{2} \mathrm{O}_{2}\right)$ concentration, with a method described by (Nishikimi et al. 1972). Results were expressed as $\mathbf{m U} / \mathbf{m l}$. Glutathione peroxidase (GPx) enzyme activity whose main biological role is to protect the organism from oxidative damage was measured according to the method described by (Beutler et al. 1963). Results were expressed as $\mathbf{m g} / \mathbf{g}$ tissue. Tissue malondialdehyde activity (MDA) levels, which reflect lipid peroxidation rate, were measured according to the method described by (Satoh, 1978 \&Ohkawa et al. 1979). Results were expressed as nmol/g tissue. Total protein was measured according to the method described by (Cornal et al. 1949). Results were expressed as $\mathrm{g} / \mathrm{dL}$. 


\section{Results}

\subsection{Body weight gain}

Average body weight gain in control groups were $47.85 \pm 3.28 \mathrm{~g} \& 25.42 \pm 3.59 \mathrm{~g}$ for $1 \mathrm{M} \& 10 \mathrm{M}$, respectively. The daily weight gain follows the same trend $(1.06 \pm 0.07 \mathrm{~g} \&$ $0.59 \pm 0.19 \mathrm{~g} /$ day) (Table 1, Fig 1).

Average body weight gain in quercetin enriched diet groups were $39.57 \pm 4.03 \mathrm{~g} \&$ $33.14 \pm 5.55 \mathrm{~g} /$ day for $1 \mathrm{M} \& 10 \mathrm{M}$, respectively. The daily weight gain follows the same trend $(2.63 \pm 0.27 \mathrm{~g} \& 2.21 \pm 0.37$ g/day) (Table 1, Fig 2). It was observed that the daily weight gain in quercetin group was higher than that of control group. In addition to normal growth, food consumption, and muscle mass, rats treated with the quercetin enriched diet did not exhibit obvious signs of toxicity including failure to groom or lethargy. Importantly, supplementation with quercetin did not result in unexpected deaths.

Table 1: Average body weight gain in control \& quercetin treatments

\begin{tabular}{llllll}
\hline \multicolumn{2}{l}{ Initial wt. $(\mathrm{g})$} & \multicolumn{2}{l}{ Final wt. $(\mathrm{g})$} & Wt. gain $(\mathrm{g})$ & Wt. gain $(\mathrm{g} / \mathrm{day})$ \\
\hline C1M & $36.42 \pm 2.43$ & Q1M & $76.00 \pm 4.51$ & $39.57 \pm 4.03$ & $2.63 \pm 0.27$ \\
C10M & $229.28 \pm 24.90$ & Q10M & $262.42 \pm 21.36$ & $33.14 \pm 5.55$ & $2.21 \pm 0.37$ \\
\hline
\end{tabular}

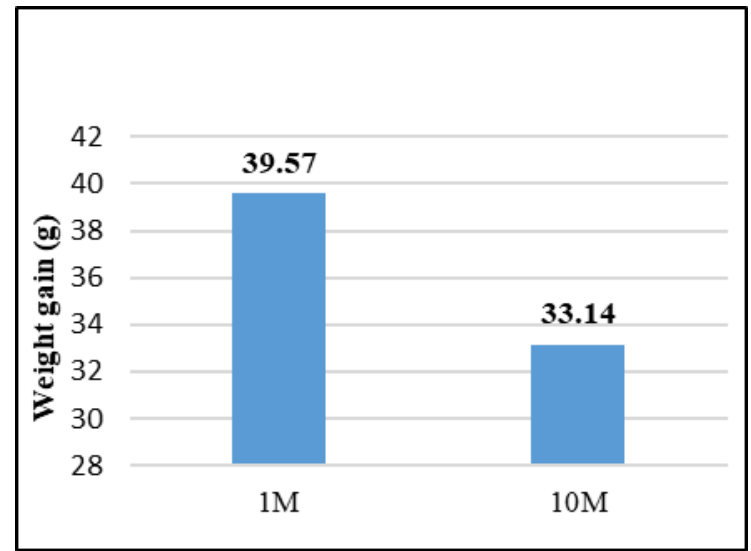

Figure (1): Effect of quercetin treatment on body gain in different ages mice.

\subsection{Oxidative Markers}

\subsubsection{Glutathione peroxidase (GPx)}

Results show a slight increase in glutathione peroxidase GPx enzyme activity in muscular tissues in control groups at different ages. Quercetin treatment increase the content of GPx in (1M) by $22.45 \%$, but decreasing GPx by $25.32 \%$ for $10 \mathrm{M}$, when compared with values of the control group (Table 2, Fig. 3).

\subsubsection{Superoxide dismutase (SOD)}

Results show a slight increase in superoxide dismutase SOD enzyme activity in muscular

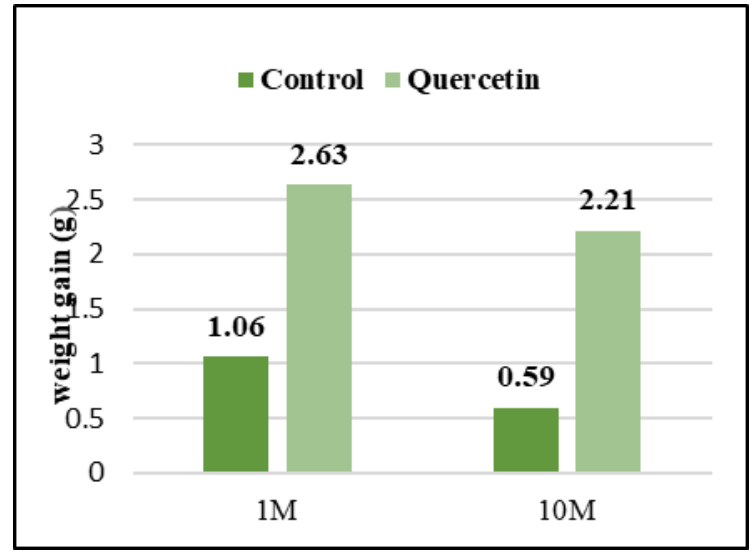

Figure (2): Effect of quercetin treatment on daily weight gain in different ages mice.

tissues in control groups at different ages, where control $(1 \mathrm{M})$ shows the lowest values and control $(10 \mathrm{M})$ shows the highest values. Quercetin treatment increases the content of SOD at different ages by $16.2 \% \& 68.15 \%$, for IM\& $10 \mathrm{M}$, respectively, when compared with values of the control group (Table 2, Fig. 4).

\subsubsection{Malondialdehyde (MDA)}

MDA content of muscular tissues of control rats $(1 \mathrm{M})$ decreases by $18.51 \%$, when comparing with control (10M) values. Treatment of Quercetin increased the levels of muscle tissue MDA level comparing with 
control. It was found that tissue MDA was respectively, when compared with value of control $1 \mathrm{M}$. When comparing quercetin treatments at different ages, it is noted the MDA content of muscular tissues decrease by $35.9 \%$ at $10 \mathrm{M}$, when compared with values of quercetin treatment $1 \mathrm{M}$. These means that there were defenses in MDA content at different ages of rats (Table 2, \& Fig.5). increased by $168.8 \% \& 110.0 \%$ at $1 \mathrm{M} \& 10 \mathrm{M}$,

\subsubsection{Total Protein}

The total protein concentration in the muscular tissues of rats was found to be slightly increase in the control group at different ages of rats. Quercetin treatments increased the total protein concentration in muscular tissues of rats at different ages. The percent increase in protein content in quercetin treatments were $50.3 \%$ \& $24.39 \%$ where compared with values of control at $1 \mathrm{M}$ \& 10M, respectively (Table 2 , \& Fig 6).

Table 2: Antioxidant parameters \& total protein in tissue muscles in control \& quercetin treatments of different mice ages.

\begin{tabular}{lllll}
\hline $\begin{array}{l}\text { Experimental } \\
\text { groups }\end{array}$ & $\begin{array}{l}\text { GPx } \\
\mathbf{m U} / \mathbf{m l}\end{array}$ & $\begin{array}{l}\text { SOD } \\
\mathbf{m U} / \mathbf{m l}\end{array}$ & $\begin{array}{l}\text { MDA } \\
\text { nmol /g tissue }\end{array}$ & $\begin{array}{l}\text { PROTEIN } \\
\text { g / dL }\end{array}$ \\
\hline $\mathbf{C}(\mathbf{1 M})$ & $52.23 \pm 5.68$ & $11.53 \pm 0.93$ & $27.00 \pm 3.60$ & $0.78 \pm 0.11$ \\
$\mathbf{Q}(\mathbf{1 M})$ & $\mathbf{6 3 . 9 6} \pm \mathbf{6 . 5 4}$ & $\mathbf{1 3 . 4 0} \pm \mathbf{1 . 7 1}$ & $\mathbf{7 2 . 6 0} \pm \mathbf{1 1 . 4 9}$ & $\mathbf{1 . 5 7} \pm \mathbf{0 . 3 5}$ \\
$\mathbf{C}(\mathbf{1 0 M})$ & $56.33 \pm 1.15$ & $13.16 \pm 1.05$ & $22.00 \pm 3.0$ & $0.93 \pm 0.06$ \\
$\mathbf{Q}(\mathbf{1 0 M})$ & $\mathbf{5 5 . 8 3} \pm \mathbf{8 . 4 3}$ & $\mathbf{2 2 . 7 0} \pm \mathbf{3 . 4 6}$ & $\mathbf{4 6 . 3 3} \pm \mathbf{5 . 1 3}$ & $\mathbf{1 . 2 3} \pm \mathbf{0 . 3 0}$ \\
\hline
\end{tabular}

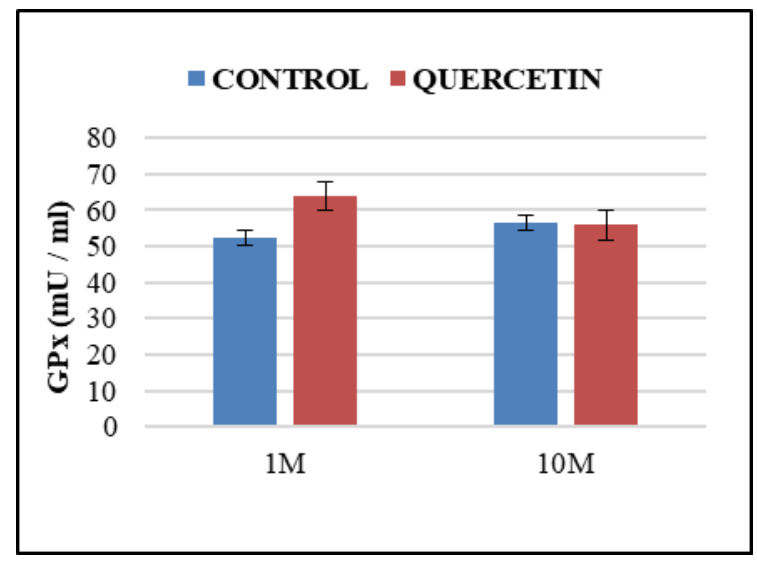

Figure (3): Effect of quercetin on glutathione peroxidase GPx enzyme activity.

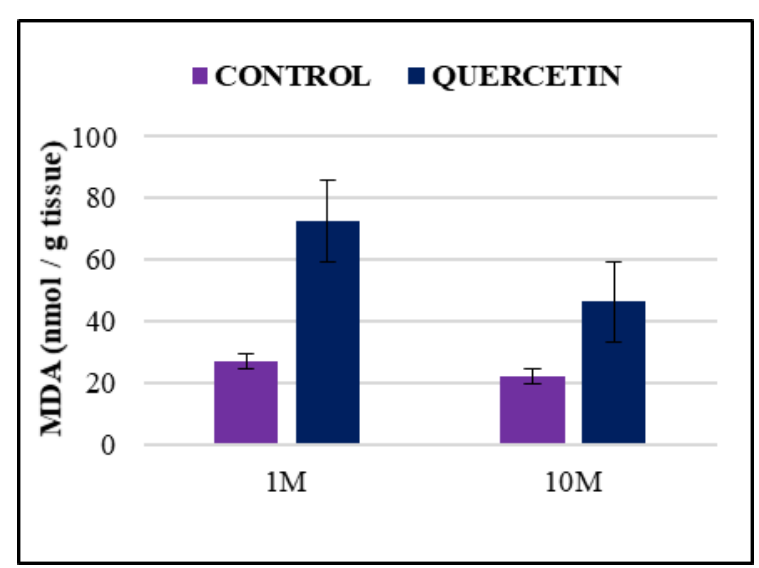

Figure (5): Effect of quercetin on malondialdehyde MDA level.

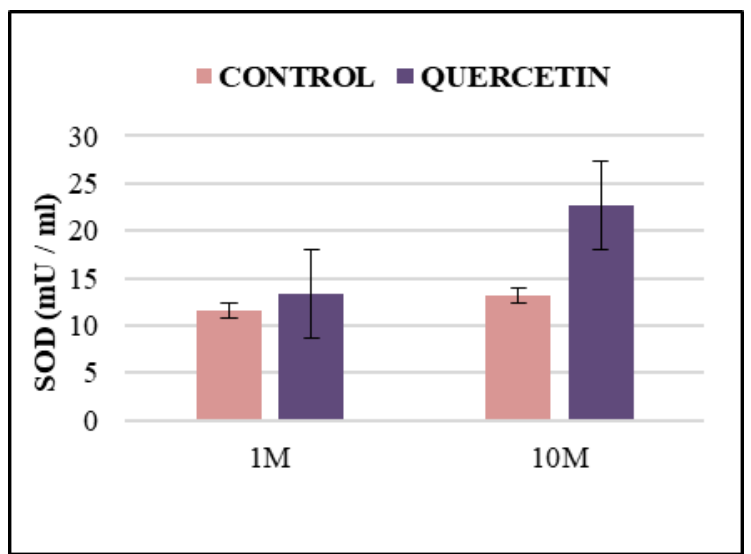

Figure (4): Effect of quercetin on superoxide dismutase SOD enzyme activity.

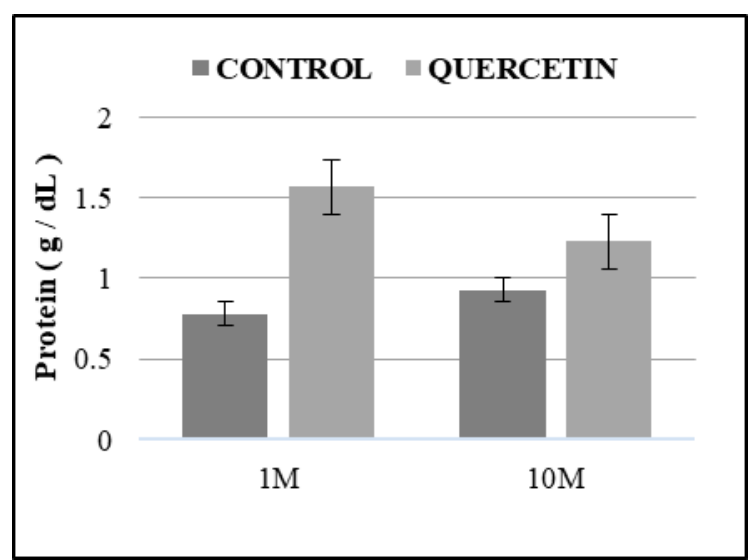

Figure (6): Effect of quercetin on total protein in tissue muscle. 


\subsection{Tissue cytological changes}

Representative (H\&E stained) histology of gastrocnemius muscle of rats treated for 15

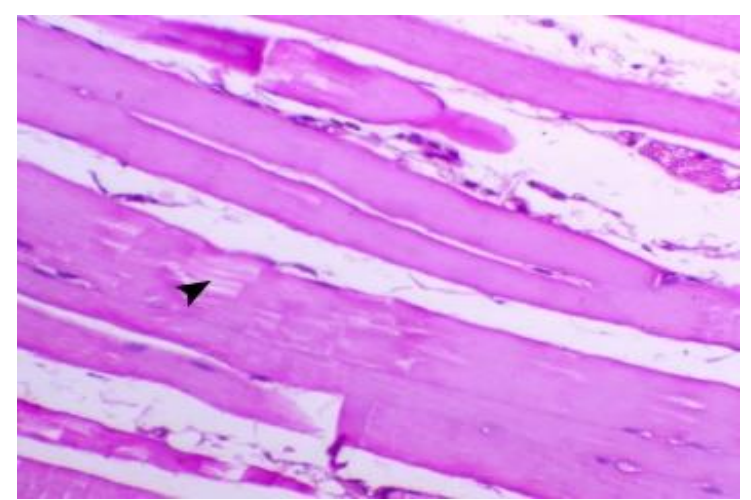

Figure (7): Skeletal muscle of non-treated animal (1 M) showing loss of the muscle fiber striation, hyalinization of muscle bundles and fragmentation of muscle fibers, H\&E, X200

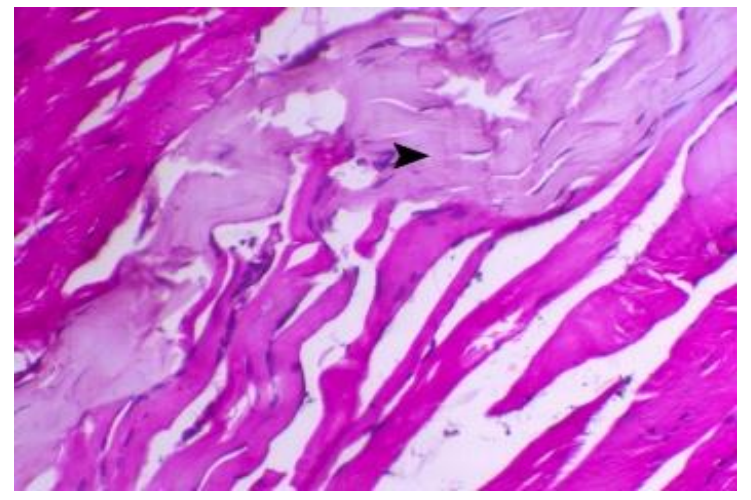

Figure (9): Skeletal muscle of non-treated animal (10M) showing marked hyalinization (arrowhead) and fragmentation of muscle fibers, H\&E, X200

\section{Discussion}

The results of this study show that he body weight in control and quercetin treated animals at different ages increased consistently and no decrease in body weight was observed throughout the experimental period. It was observed that the daily weight gain in quercetin treatment group was higher than that of control group by $148 \% \& 275 \%$ for $1 \mathrm{M} \& 10 \mathrm{M}$, respectively. In addition to normal growth, food consumption, and muscle mass, rats treated with the quercetin enriched diet did not exhibit obvious signs of toxicity including failure to groom or lethargy. Importantly, supplementation with quercetin did not result in unexpected deaths. days with different doses of quercetin at the end of experiment (Fig. 7-10).

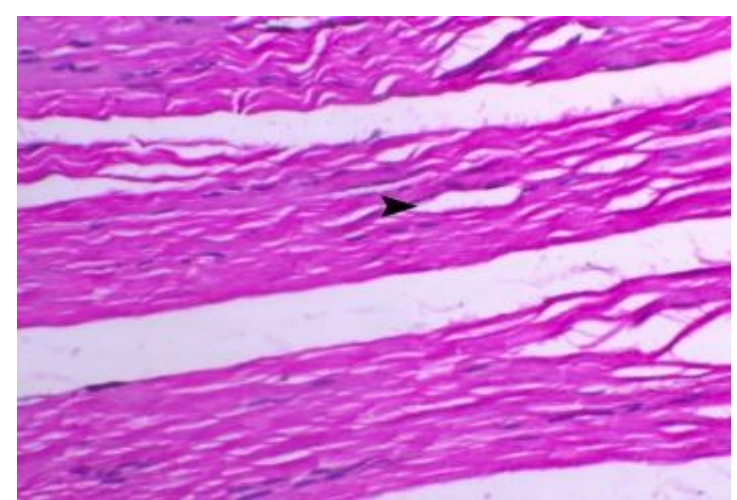

Figure (8): Skeletal muscle of Quercetintreated animal $(1 \mathrm{M})$ showing focal myolysis of skeletal muscle fibers (arrowhead), H\&E, X200.

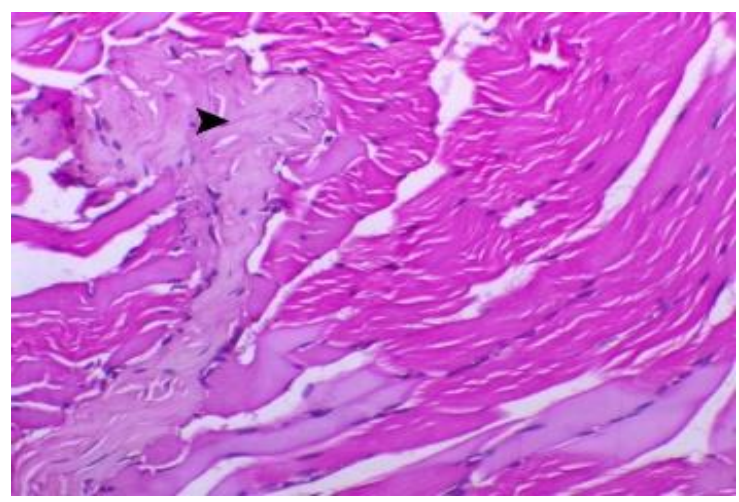

Figure (8): Skeletal muscle of Q-treated animal (10M) showing focal hyalinization of muscle fibers (arrowhead) while the remaining bundles were within normal, $\mathrm{H} \& \mathrm{E}$, X200.

In this study, the effect of dietary quercetin at a rate of $4 \mathrm{mg} / \mathrm{kg}$ body weight per day on growth performance and oxidative markers body weight per day on growth performance and oxidative markers in the gastrocnemius muscular tissues of rats of different ages were in the gastrocnemius muscular tissues of rats of different ages were examined. Several studies have promoted quercetin as excellent antioxidants in vivo (Maalik et al. 2014; Dong et al 2014; Alrawaiq\& Abdullah 2014). Separately from its antioxidant capacity, quercetin also possesses antitumor activity against different cancer cell types (Kanadaswami et al. 2005). 
Lipid peroxidation results in cellular injury, causing structural and functional alterations in the cells (Gulcin et al. 2003 \& Henderson et al. 2010). SOD and GPx are known as endogenous antioxidants, and the first-line defense mechanism against free radical damage (Glucin et al. 2002; Birdane et al. 2007). These enzymes catalyze the conversion to less reactive species of the derived-oxygen radicals (Elmastas et al. 2006). SOD is an important part of the antioxidant defense for the organisms. When the extreme $\mathrm{O}_{2}{ }^{-}$occurs, SOD reduces the amount of superoxide radicals $\left(\mathrm{O}_{2}^{-}\right)$by converting to oxygen $\left(\mathrm{O}_{2}\right)$ and hydrogen peroxide $\left(\mathrm{H}_{2} \mathrm{O}_{2}\right)$ (Bannister et al. 1987; Elmastas et al. 2006). GPx protects the tissues against free radicals by limiting lipid peroxidation. Furthermore, measurement of changes in antioxidant enzyme activity can give an idea about the amount of ROS, indirectly (Şentürk et al. 2008). Quercetin obviously, induced SOD and GPx gene expressions as well as enhanced their enzyme activities. Additionally, quercetin reduced the increased MDA and protein carbonyl levels (Almaghrabi, 2014).

In this study, GPx in control (1M) rats increased by $22.45 \%$, but decreasing by $25.32 \%$ in $10 \mathrm{M}$ rats, when compared with values of the control group. SOD increased by $16.2 \%$, \& $68.15 \%$ for IM\& $10 \mathrm{M}$ rats, respectively, when compared with values of the control when comparing quercetin treatments at different ages, it is noted the MDA content of muscular tissues decrease by $58.0 \%$ at $10 \mathrm{M}$ rats, when compared with values of quercetin treatment $1 \mathrm{M}$.

Studies by Molina et al. (2003) tested the effect of quercetin on mice showed that quercetin has a protective effect against oxidative stress in hepatic tissues by increasing the ratio of GSH/GSSG. The results also show higher GPx activity in liver compared with the control group. Also, the level of hepatic SOD, GR has also been improved, and the level of malondialdehyde (MDA) which is a marker for lipid peroxidation in liver has been decreased by the quercetin treatment. In another study,
Galvez et al. (1994) used orally administrated quercetin on rats. The result showed that compared with the control group, the treatment group has higher GSH/GSSG ratio in hepatic tissue. Meyers et al. (2008) demonstrated that both dietary quercetin and dietary dried onion have an effect on upregulation of GSH/GSSG ratio in liver, but the effect was not found in cardiac tissues or plasma. The study conducted by Coskun et al. (2005) on diabetic rats shows that the activity of GPx in pancreatic homogenates increased significantly. Another study using diabetic rats conducted by Sanders et al. (2001) also shows that a dose of $10 \mathrm{mg} / \mathrm{kg} /$ day quercetin lead to an increase of renal and cardiac GPx activity.

Another study conducted on rats also shows the improved oxidative status in liver by dietary quercetin treatment (Odbayar et al., 2009). Study conducted by Van Le Thanh., et al. (2016) demonstrated the protective effect of quercetin on pig liver. Other studies have also showed the effect of quercetin treatment on liver by the increased GSH/GSSG ratio, regulation of related enzymes, and reduced lipid oxidation (Galvez et al., 1994; Meyers et al., 2008; Olayinka et al., 2014; Sanders et al., 2001).

Skeletal muscles of non-treated rats at age $1 \mathrm{M} \&$ 10M show marked Caspace3 immunostaining (degree $++\&$ (degree +++++ ), respectively; whereas quercetin treatment rats at age $1 \mathrm{M} \& 10 \mathrm{M}$ showing decrease of Caspace 3 immunostaining (degree + ) \& (degree +++ ) respectively when compared to normal (untreated) rats at the same age.

\section{Conclusion}

From a critical evaluation of the available literature on the biological effects of quercetin, including data related to safety, it may be concluded that quercetin, at estimated dietary intake levels, would not produce adverse health effects.

\section{Acknowledgments}

This research was supported by the authors of this study who thanks all members in Faculty of science, Tanta University, Egypt. 


\section{Conflict of Interest}

The authors declare that there is no conflict of interest.

\section{References}

Aebi, H. (1984). Catalase in vitro. Methods Enzymol 105, 121-126.

Almaghrabi O.A. (2015). Molecular and biochemical investigations on the effect of quercetin on oxidative stress induced by cisplatin in rat kidney. Saudi Journal of Biological Sciences. Vol. 22 (2): 227-231.

Alrawaiq N.S., \& Abdullah A. (2014). A Review of Flavonoid Quercetin: Metabolism, Bioactivity and Antioxidant Properties. Int. J. Pharm. Tech. Res. 6: 933-941.

Bannister J.V., Bannister W.H., \&Rotilio G. (1987). Aspects of the structure, function, and applications of superoxide-dismutase. CRC Crit Rev Biochem 22:111-80.

Beutler E., Duron O., \& Kelly M.B. (1963). Improved method for the determination of blood glutathione. J. Lab. Clin, Med. 61, 882-888.

Birdane F.M., Cemek M., Birdane Y.O., et al. (2007). Beneficial effects of Foeniculum vulgare on ethanol-induced acute gastric mucosal injury in rats. World J Gastroenterol. 13:607-611

Bors W., Heller W., Michel C., Saran M. (1990). Flavonoids as antioxidants. Determination of Radical-Scavenging Efficiencies. In: Packer L, Glazer AN, editors. Methods in Enzymology. Vol. 186. San Diego CA: Academic Press; 1990. pp. 343-355.

Coskun, O., Kanter, M., Korkmaz, A., \&Oter, S. (2005). Quercetin, a flavonoid antioxidant, prevents and protects streptozotocin-induced oxidative stress and beta-cell damage in rat pancreas. Pharmacol Res, 51(2): 117-123

Dong Y., Wang J., Feng D., Qin H., Wen H., Yin Z., Gao G., \& Li C. (2014). Protective Effect of Quercetin against Oxidative Stress and Brain Edema in an Experimental Rat Model of Subarachnoid Hemorrhage. Int. J. Med. Sci, 11: 282-290.

Elmastas M., Türkekul I., Öztürk L., et al. (2006). The antioxidant activity of two wild edible mushrooms (Morchella vulgaris and Morchellaesculanta). Comb Chem High Through Scr. 9:443-448

Fossati, P., Prencipe L., \&Berti G. (1980). Use of 3,5dichloro-2-hydroxybenzenesulfonic acid/ 4aminophenazone chromogenic system in direct enzymic assay of uric acid in serum and urine. Clin. Chem. 26, 227-231

Galvez, J., de la Cruz, J. P., Zarzuelo, A., Sanchez de Medina, F., Jr., Jimenez, J., \& Sanchez de la Cuesta, F. (1994). Oral administration of quercetin modifies intestinal oxidative status in rats. Gen Pharmacol, 25 (6): 1237-1243.

Gornal A.G., Bardawill C.J., \& David M.M. (1949). Determination of serum proteins by means of the biuret reaction. J. Biol. Chem. 177 (2):751-766.

Gülçin I., Beydemir Ş., Hisar O., et al. (2009). Melatonin administration increases antioxidant enzymes activities and reduce lipid peroxidation in the rainbow trout (Oncorhynchus mykiss, Walbaum) erythrocytes. Turk. J. Vet. Anim. Sci. 33:241-246.

Gulcin I., Oktay M., Kirecci E., \&Kufrevioglu O.I. (2003). Screening of antioxidant and antimicrobial activities of anise (Pimpinellaanisum L.) seed extracts. Food Chem. 83:371-8

Gulcin I., Oktay M., Kufrevioglu O.I., \& Aslan A. (2002). Determination of antioxidant activity of lichen Cetrariaislandica (L) Ach. J Ethnopharmacol. 79:325-329

Harborne J.B. (1995) editor. London: Chapman \& Hall. The Flavonoids, Advances in Research Since 1986; pp. 378-382.

Henderson P.W., Singh S.P., Weinstein A.L., et al. (2010). Therapeutic metabolic inhibition: hydrogen sulfide significantly mitigates skeletal muscle ischemia reperfusion injury in vitro and in vivo. Plast. Reconstr. Surg. 126:1890-1898

Kanadaswami C., Lee L., Lee P.H., Hwang J., Ke F., Huang Y., \& Lee M. (2005). The Antitumor Activities of Flavonoids. In vivo 19: 895-910.

Maalik A., Khan F.A., Mumtaz A., Mehmood A., Azhar S., Atif M., Karim S., Altaf Y., \& Tariq I. (2014). Pharmacological Applications of Quercetin and Its Derivatives: A Short Review. Trop. J. Pharm. Res. 13: 1561-1566.

Meyers, K. J., Rudolf, J. L., \& Mitchell, A. E. (2008). Influence of dietary quercetin on glutathione redox status in mice. J. Agric. Food. Chem., 56 (3): 830836.

Molina, M. F., Sanchez-Reus, I., Iglesias, I., \&Benedi, J. (2003). Quercetin, a flavonoid antioxidant, prevents and protects against ethanol-induced oxidative stress in mouse liver. Biol Pharm Bull, 26 (10): 1398-1402.

Nishikimi, M., Roa, N.A., Yogi, K. (1972). Measurement of superoxide dismutase. Biochem. Biophys. Res. Common, 46: 849-854. 
Odbayar, T. O., Kimura, T., Tsushida, T., \& Ide, T. (2009). Isoenzyme-specific up-regulation of glutathione transferase and aldo-keto reductase $m R N A$ expression by dietary quercetin in rat liver. Mol Cell Biochem, 325 (1-2): 121-130.

Ohkawa H., Ohishi W., \& Yogi K. (1979). Assay for lipid peroxides in animal tissues by thiobarbituric acid reaction. Anal. Biochem. 95 (2): 351-358.

Olayinka, E. T., Ore, A., Ola, O. S., \&Adeyemo, O. A. (2014). Protective effect of quercetin on melphalaninduced oxidative stress and impaired renal and hepatic functions in rat. Chemother. Res. Pract., 2014, 936526. doi:10.1155/2014/936526

Paglia D.E. \& Valentine W.N. (1967). Studies on the quantitative and qualitative characterization of erythrocyte glutathione peroxidase. J. Lab. Clin. Med. 70 (1): 158-169

Sanders, R. A., Rauscher, F. M., \& Watkins, J. B., 3rd. (2001). Effects of quercetin on antioxidant defense in streptozotocin-induced diabetic rats. J Biochem Mol Toxicol, 15 (3): 143-149.

Satoh, K. (1978). Plasma lipid peroxide in cerebrovascular disorder determined by a new colorimetric method. Clinica. Chimica. Acta, $90: 37-43$.

Şentürk M., Gülçin I., Çiftci M., \&Küfrevioğlu Ö.I. (2008). Dantrolene inhibits human erythrocyte glutathione reductase. Biol. Pharm. Bull. 31:20362045.

Van Le Thanh, B., Lemay, M., Bastien, A., Lapointe, J., Lessard, M., Chorfi, Y., \&Guay, F. (2016). The potential effects of antioxidant feed additives in mitigating the adverse effects of corn naturally contaminated with Fusarium mycotoxins on antioxidant systems in the intestinal mucosa, plasma, and liver in weaned pigs. Mycotoxin Res, 32

(2):

99-116. 